\title{
Feasibility Test for Multimedia Learning in Mu'allimin Muhammadiyah Madrasah of Yogyakarta, Indonesia
}

\author{
Muhammad Lailan Arqam \\ Ahmad Dahlan University, Yogyakarta, Indonesia \\ Arqam1503@gmail.com
}

\begin{abstract}
This study discusses about the feasibility test for multimedia learning in Mu'allimin Muhammadiyah madrasah of Yogyakarta, Indonesia. The results shows that the multimedia developed has an attraction that can bring out and increase student interest and motivation. While a total of 26 students in other words a total of $87 \%$ of the trial subjects used chose the "No" assessment criteria for the component of the difficulty level. As well as $13 \%$ or 4 other students say "yes". This shows that the developed multimedia learning is easy to understand and helps students to understand the kemuhammadiyahan learning material. A total of 24 students using trial subjects chose the "Yes" assessment criteria for the benefits of learning multimedia, if used in the form of a percentage it showed an amount of $80 \%$. Students feel more helpful in learning with the emergence of a sense of comfort in learning using multimedia learning developed. And they can improve learning outcomes on kemuhammadiyahan subjects. While 20\% of students answered "No", considering multimedia did not help in the learning process.
\end{abstract}

Keywords : multimedia learning; Mu'allimin Muhammadiyah Madrasah

\section{Introduction}

Computers are technological tools that can be used as alternatives in the learning process. With the help of computer technology can be made a fun learning media. With computer technology can simplify and clarify material that is so diverse and can provide concrete examples. With computer technology can also make students learn according to their speed and ability to learn.

Multimedia is a combination of text, graphics, audio, motion pictures (animations and videos) that can make the user attractive. With this advantage, making multimedia is used in the learning process. Through multimedia, users / learners do not only involve existing sensory abilities and have the power of attraction alone, but also can provide good stimulants in responding to comprehensively taught knowledge.

This is reinforced by Sri Anitah (2009: 61) in a book called Media learning said that: multimedia systems may consist of a combination of traditional media that is connected to a computer to present text, graphics, images, sound, and video. Multimedia involves more than just integrating these forms into a structured program, which consists of elements complementing one another.

Kemuhammadiyahan as one of the subjects at the Mu'allimin Muhammadiyah Madrasah of Yogyakarta, these subjects have an important role to play in relation to the vision and mission of the Madrasah, which declares itself to be a prospective school cadre of the Muhammadiyah community organizations in Indonesia. However, in the field, the Kemuhammadiyahan learning process still seems tedious, passive and boring. This is clearly seen with no use of media and variations in methods in learning and learning models that are still teacher-centered (teacher centered). The teaching material book is the only learning guide for students in learning. For this reason, in this study, researchers wanted to develop computerassisted learning media, which was later termed as kemuhammadiyahan multimedia learning. 
The development of multimedia learning on Kemuhammadiyahan subjects, is one of the efforts made in improving the quality of learning processes and outcomes. With this multimedia learning, it is expected to be able to overcome the problems at hand. Like the monotonous learning process, the learning model is still teacher-centered, students who are passive in learning, lack of variations in learning and saturation when learning takes place.

\section{Review of Literature}

\subsection{Multimedia}

Multimedia is a combination of various media: text, graphics, images, videos. This can also be interpreted as the use of computers to create and combine graphics, text, audio, images, and video / animation. By combining links and tools that allow users to navigate, interact, create, and communicate (M. Suyanto, 2005: 21). Various media are combined into one that will present information that has more value. This also suggests that AI, Constantinescu (2007: 2) states that "Multimedia refers to computer-based systems that use various types of content, such as text, audio, video, graphics, animation, and interactivity" (Multimedia refers to computer-based systems that use various types of content such as files, audio, video, graphics, animation, and interactivity).

Sri Anitah (2008: 61) says: bahwas the multimedia system involves more than the integration of forms into a structured program, which consists of elements that complement each other. Multimedia systems may consist of a combination of traditional media that is connected to a computer to present text, graphics, images, sound, and video. This opinion is in line with Smaldino in Sri Anitah (2008: 60) saying that multimedia deals with the use of various types / forms of media that are sequential and simultaneous in presenting information.

N., Chapman \& J., Champman, (2004: 8) states that the form of multimedia as a message delivery tool is divided into two, namely online delivery and offline delivery. The definition of multimedia that uses a network to convey information from one computer or server machine that is the center of other network data storage both local networks within an organization and the internet is called the online delivery system. Whereas, what is meant by offline delivery is multimedia that is stored using a removable storage or packaging device. The storage device must be able to store large data in accordance with the characteristics of multimedia data, for example DVD and CD-Rom.

\subsection{Classification of Learning Media}

According to Rudi and Cepi (2008: 13-22) there are many variations in the classification of learning media which are grouped into seven groups, namely: First Group; (a) Graphic Media, is a visual media that presents facts, ideas to know ideas through the presentation of words, sentences, numbers, and symbols / images. Graphics are usually used to attract attention, clarify the presentation of ideas, and illustrate facts so that they are interesting and easy to remember. Including graphic media are graphics, diagrams, charts, sketches, posters, flannel boards, and bulletin boards. (b) Print Material Media, is the visual media that makes it through the process of printing / printing or offset. This media presents its message through letters and images illustrated to clarify the message or information presented. This form of media is like; bukuteks, modules, and programmed teaching materials. (c) Silent Image Media, is visual media in the form of images produced through photography. This type of media is a photo. 
Second group; Projected media are still projected visual media or media that project messages, where the projection results are not moving. These types of media include; OHP / OHT, Opaque projector, slides, and filmstrip. Third group; Audio media, is the media whose delivery of messages can only be received by listeners. Messages or information are poured into auditive in the form of words, music, and sound effects. Fourth group; Silent audio-visual media, are media whose delivery of messages can be received by the sense of hearing and sight, but the resulting image is a still image or a little element of motion. These types of media include sound slide media, sound film strips, and sound pages.

Fifth group; Films, often referred to as motion pictures, are series of still images (still pictures) that slide quickly and projected to give the impression of life and movement. In the film presents audiovisual and moving messages. Therefore, the film gives an impressive message to the audience. Sixth group; Television, this media is the same as the film that displays audiovisual messages and moves. What distinguishes this media from its open type factor (open boardcast television), limited (cole circuit televirion / CCTV) and video-cassete recorder (VCR).

Seventh group; Multimedia, is a delivery system that uses various types of learning materials consisting of printed, audio, and audiovisual materials. This type of media is object media and interactive. According to Heinich, Molenda, Russel, Smaldino (1996: 8), there are several media that can be used in learning activities:

a. Non-projected media, such as pictures / photos, diagrams, exhibitions, and models.

b. Projected media, such as: slides, filmstrips, OHPs, and projected computers.

c. Audio media (audio media), such as: tapes and CDs.

d. Motion audio (moving media), such as: videos and movies.

e. Computer-mediated instruction.

f. Computer-based multimedia and hypermediai (computer-based and hypermedia multimedia).

g. Media, such as radio and television used in distance learning.

\subsection{Kemuhammadiyahan}

Kemuhammadiyahan subjects are one of the subjects typical of Mu'allimin Muhammadiyah Madrasah of Yogyakarta. Especially with its position as a school founded directly by the founder of Muhammadiyah Kyai Haji Ahmad Dahlan in 1920. This is clearly seen with the vision, mission, goals, and competencies of madrasah graduates as follows: (http //www.muallimin.org).

Mu'allimin Muhammadiyah Madrasah of Yogyakarta is a superior middle-level Muhammadiyah educational institution and is able to produce cadres of clerics, leaders and educators as bearers of the mission of the Muhammadiyah movement. This school mission is:

a. Organizing and developing Islamic education is used to build students' competencies and excellence in the fields of Islamic sciences, science, technology, art, and culture.

b. Organizing and developing Arabic and English language education as a communication tool to explore religion and science.

c. Organizing and developing leadership education in order to build student competency and excellence in the field of morality and personality.

d. Organizing and developing teacher education to build the competency and excellence of students in the field of education. 
e. Organize and develop skills education to build the competency and excellence of students in the field of Entrepreneurship.

f. Organizing and developing the education of Muhammadiyah cadres to build students' competence and excellence in the field of organization and struggle of Muhammadiyah.

The implementation of secondary education that excels in forming cadres of scholars, leaders, and educators who support the achievement of Muhammadiyah's goals, namely the realization of the true Islamic community.

Competence is the basic ability of Mu'allimin Muhammadiyah Madrasah of Yogyakarta graduates who are formed after the concerned has taken an education, guidance and training program at a certain level and time. The basic ability can be measured by the standard qualifications of abilities inherent in abiturien, mastery of a number of knowledge, personality, and skills in a number of certain skills.

The purpose of the basics of competence is a number of basic and basic abilities that must be at least attached to Mu'allimin Muhammadiyah Madrasah of Yogyakarta graduates as the main basis for desired self-formation (shibghah). As a Persyarikatan cadre school, the competencies built in this madrasah must at least include competencies as formulated in the Muhammadiyah Cadre System, namely: religious competence, academic-intellectual competence, and social humanitarian competence.

\section{Discussion}

At this stage, the researcher met with a multimedia learning expert who was also a media lecturer at the postgraduate program at Sebelas Maret University in Surakarta, named Sri Anitah. She is one of the professors who has a scientific background and basic knowledge in the field of educational technology since he took the first to third strata, and is an expert in the field of learning media. This meeting took place in the UNS postgraduate education technology department. This meeting was not the first thing the researchers did, because long before the researchers' thesis proposal had been made, he had submitted a request for him to be a media expert in planning the development of multimedia learning that the researcher did in his thesis assignment.

In this follow-up meeting, the researcher gives an evaluation form that is reviewed from 7 (seven) components taken in accordance with the theory that the researcher described in chapter II, the assessment consists of; text, color, animation / image, music / sound, grammar, layout, and interactivity. The initial assessor began by looking closely at the multimedia products that researchers have developed by media experts. While scrutiny is carried out, media experts give notes on the evaluation sheet held, and ask a number of questions such as why choose chemistry subjects? Who is the maker of animation in this multimedia ?, and the researcher answers as multimedia takes place with short sentences.

After the observation, the media expert gave a check mark on the column for the learning media expert evaluation sheet. The evaluation results show that in general multimedia that has been developed is included in the good category. However, there are several important notes as input in improving multimedia learning in Kemuhammadiyahan subjects that the researchers developed. The notes are: (1) it is necessary to add an introduction before entering the material with voice to give attention to the user, (2) added learning goals to foster students' interest and motivation in learning, (3) need to be given the identity of the user so as not to misunderstand 
the user and the last (4) added background music interspersed with fade in-fade out music vaguely to create a comfortable atmosphere for the wearer.

After meeting with media experts, the researcher met with Ms. Misma Kasim, MA. as the material expert of Kemuhammadiyahan. She is a lecturer at Ahmad Dahlan University or also known as the abbreviation UAD. The university is a campus which is still under the auspices of the Muhammadiyah Society, and he is one of the teaching staff at the Muhammadiyah Central Leadership School in Mu'allimin Muhammadiyah Madrasah of Yogyakarta who has taught at Kemuhammadiyahan subjects and was one of the makers of the Kemuhammadiyahan subject curriculum in 2007 which is currently still in use. He is still actively involved as one of the administrators at the level of the Muhammadiyah Central Executive and the Central Executive 'Aisyiyah in the Cadre Education Council, which is responsible for regeneration in the Persyarikatan.

The meeting took place at his home in the Pathuk area of Yogyakarta at night at 18.3020.25 WIB. Starting the meeting, the researcher conveys the intent and purpose in developing multimedia learning. After giving the opening talk, the researcher gave the material expert evaluation sheet, then presented the multimedia results that had been developed. Material experts look carefully until there is no conversation whatsoever when multimedia is displayed. After the observations were made by material experts, they immediately submitted notes and comments by stating that the material from the multimedia developed included good and right categories. But there are some of his notes as follows: (1) expected to change the name of prayer in multimedia questions written istihah prayers and istiqlal prayers to be the name of the appropriate prayer, such as dhuha prayer and tahajud prayer, (2) in the third question on learning multimedia evaluation replaced from "Yes" becomes "well", (3) he suggests that you can create Kemuhammadiyahan multimedia that includes all Kemuhammadiyahan material.

Departing from the assessment and advice of media experts and material experts, the researchers made improvements to the learning multimedia of Kemuhammadiyahan as a step in media validation and efforts in order to continue the next step of research development, namely product testing and usage testing.

After the improvement of multimedia learning was carried out, the researcher continued on the product testing phase in three students. Voters of three students were taken according to their abilities from the results of the Kemuhammadiyahan subject matter in class I. The level of ability of the three students differed from one another, consisting of low-ability students who got grades 6 , capable of intermediates who scored 7 , and highly capable value 8 . This difference is intentionally created to see the multimedia capabilities developed can accommodate students from different ability backgrounds.

In the early stages of product testing, the researcher gave an explanation of the instructions for use and all what students had to do. The third attitude of the students was quite enthusiastic when he first received an explanation while seeing the multimedia products being tested. Students seemed to notice some instructions from researchers about the trial procedure. After receiving an explanation, the three students seemed to concentrate, be absorbed, and enjoy using multimedia. Some students learn material sequences such as procedures that begin by reading the learning material up to the evaluation stage, but there are also those who jump in as they wish. In general, the learning process is quite conducive, because the number of subjects is still small and researchers can control it well.

At the product testing phase, it ended with the distribution of evaluation sheets given by the researchers to the students. They also listen to the researcher's request by accepting the 
sheet and writing down the assessment in accordance with the personal judgment. From the evaluation sheet data shows, all students assess the presence of multimedia learning that has been developed can spur motivation, interest, and help students in learning subjects Kemuhammadiyahan. and also assess that multimedia developed is easy to understand, in other words that multimedia is easy to use and brings positive benefits in improving learning processes and outcomes for students in deepening the subject matter of Kemuhammadiyahan. At the end of the multimedia evaluation assessment at the testing stage of this product, students gave suggestions so that researchers could reproduce the material if necessary all the material in class I on Kemuhammadiyahan subjects, not limited to just two chapters as in multimedia developed by researchers.

This suggestion shows students' enthusiasm in using multimedia learning. However, researchers cannot fulfill these suggestions because of the limitations possessed by researchers in development. Good time constraints, because this multimedia is the final task of the researcher in completing the thesis at the UNS postgraduate which has a certain time limit, and certainly requires a relatively long time in making multimedia which covers the entire Kemuhammadiyahan material in the Mts / SMP class I because it covers for one year. Limited funds, which require a lot of budget expenditure. As well as limited capabilities, those who still need to study more deeply also the ability to apply the macromedia flash program to researchers.

The final step of the multimedia development series is the usage trial. In the trial this usage has a difference with the previous trial stages. Because this stage is carried out on more subjects, there are 30 students in class I consisting of students from various classes I A to I E of the Mu'allimin Muhammadiyah Madrasah. This selection has adjusted the variety of abilities of students ranging from those who are low, medium, and high. In this election researchers did not experience difficulties because in the Mu'allimin Muhammadiyah Madrasah had classified their students at the beginning of each school year.

The beginning of the use trial meeting accompanied by the teacher began with giving an explanation of the instructions that need to be done by each student. As the explanation is heard by students, the enthusiasm is clearly seen by students by looking at the learning multimedia products that are being tested and also taking seriously some researchers' instructions about the usage procedures, starting from the multimedia usage method, time sharing, and filling out the evaluation sheet questionnaire information done by students.

In the process of using multimedia learning takes place, all students appear to be concentrated and enthusiastic in using multimedia learning. Some students give input to other students about interesting things from the material by asking their friends to try to see cartoons that make them smile and laugh which is considered funny. There are also some students who approach other students to discuss related material that is considered new. Shiva's voice seemed boisterous to experiment with using multimedia. Overall the learning process is clearly more fun, cheerful, and conducive until the time that has lasted for forty-five minutes ends does not feel.

At the end of the trial, the evaluation sheet was distributed. After the division is given to each student, then the students fill in the suggestions and comments and check the available column. There are some students asking for the questionnaire component which they think is unclear, such as the question sentence on the instrument the question "is multimedia easy to understand?". In this step there are not many significant obstacles, everything goes according to the expectations of researchers and students who can be invited to cooperate during the 
process. All students seemed absorbed in filling out questionnaires based on their responses and input objectively on learning multimedia products.

The results of the questionnaire assessment of the usage trial responses showed all the test subjects who were 30 students choosing the "Yes" assessment criteria for the attraction component. This means that the multimedia developed has an attraction that can bring out and increase student interest and motivation. While a total of 26 students in other words a total of $87 \%$ of the trial subjects used chose the "No" assessment criteria for the component of the difficulty level. As well as $13 \%$ or 4 other students say "yes". This shows that the developed multimedia learning is easy to understand and helps students to understand the kemuhammadiyahan learning material. A total of 24 students using trial subjects chose the "Yes" assessment criteria for the benefits of learning multimedia, if used in the form of a percentage it showed an amount of $80 \%$. Students feel more helpful in learning with the emergence of a sense of comfort in learning using multimedia learning developed. And they can improve learning outcomes on kemuhammadiyahan subjects. While $20 \%$ of students answered "No", considering multimedia did not help in the learning process.

In general, the comments and conclusions given by the subject students of the trial on the use of multimedia components are good. Some test subjects used the input to expand the display of learning material, add music, and add variety of material if necessary all the kemuhammadiyah subject matter in class I along with other subjects. But this was not done by researchers, because in consideration of time, funding and ability limitations. This was felt enough by the responses and comments of multimedia experts and chemistry subject matter experts in the Muhammadiyah.

\section{Conclusion}

Development of multimedia learning in Kemuhammadiyahan subjects is done by developing several aspects, namely: (a) Text Aspect; (b) Color Aspects; (c) Animation and Image Aspects; (d) Material Aspects; (e) Sound Aspects; (f) Interactive aspects.

Products as Kemuhammadiyahan's learning multimedia model produced in this study were declared feasible. Based on multimedia experts and learning material experts, overall multimedia learning in the subjects of the Muhammadiyah class of Mu'allimin Muhammadiyah with the introduction of Muhammadiyah material is categorized as appropriate for use in learning. As well as based on the use test, the feasibility of multimedia learning on the subjects of Muhammadiyah Muhammadiyah I / VII class I / VII in the introduction material of Muhammadiyah includes:

a) Component of attraction

This developed multimedia has an attraction that can bring out and increase learning interest and motivation.

b) Component level of difficulty

Multimedia learning that is developed is easy to understand and helps students to understand kemuhammadiyahan learning material.

c) Component benefits

Students feel the benefits of multimedia learning developed with the emergence of a sense of comfort in learning and can improve learning outcomes in kemuhammadiyahan subjects. 


\section{References}

Anas Sudijono. 2001. Pengantar Statistik Pendidikan.Jakarta: PT. Raja Grafindo Persada.

Arief Sadiman. 2003. Media Pendidikan. Jakarta: PT. Raja Grafindo Persada.

Arief Sadiman. 2001. Interaksi dan Motivasi Belajar Mengajar. Jakarta: PT. Raja Grafindo Persada.

Asri Budiningsih. 2003. Belajar dan Pembelajaran. Yogyakarta: Fakultas Ilmu Pendidikan. UNY.

Asri Budiningsih. 2005. Belajar dan Pembelajaran. Jakarta: PT. Rineka Cipta

Azhar Arsyad. 2003. Media Pembelajaran. Jakarta: Rajawali pers.

Bachtiar Sjaiful Bachri. 2002. Pengembangan bahan pembelajaran berbantuan komputer untuk memfasilitasi belajar mandiri dalam mata kuliah desain pesan pada program $S-1$ Teknologi Pendidikan Universitas Negeri Surabaya.Tesis: UNS

Chapman, N. \& Chapman, J., 2004.Digital multimedia(Second Edition).London: John Wiley \& Sons, Ltd.

Constantinescu, A.I., 2007. "Using technology to assist in vocabulary acquisition and reading comprehension". Hal 5.The internet TESL Journal, vol. XIII, No.2.dari http://iteslj.org/Articles/Constantinescu-Vocabulary.html

Degeng, I Nyoman Sudana. 1989. Ilmu pengajaran taksonomi variabel. Jakarta: Depdikbud

Depdikbud. 1988/1989. Pedoman Penilaian Media Pendidikan. Jakarta: Depdikbud. Direktorat Sarana Pendidikan.

DePorter Bobbi \& Mike Hernacki, 2000. Quantum Learning.Bandung: Kaifa.

Djauhar Siddiq. 2005. Pembelajaran Visual Model Video Critique. Majalahilmiahpembelajaran, 1, 57-72

Flecter, J.D. 2007.Learning Any Time Any Where: Advanced Distributed Learning and The Changing Face of Education. Educational Research Association, 36, 96-102

Gall Borg, Walter, and Meredith Damien, 1989. Educational Research. New York\&London : Longman.

Heinich, Molenda, Russel, Smaldino. 1996. Instructional Media and Technologies for Learning. New Jersey: Printice-Hall, Inc. A Simon \& Schuster Company.

Http://www.pustaka.usm.my/docushare/dsweb/GetRedition/Document=12907/ htm.

Kok Yung. 2006. TeknikProfesional Flash MX 2004.Jakarta: Alex Media Komputindo.

M. Suyanto. 2005 Multimedia alat untuk Meningkatkan Mutu Bersaing. Yogyakarta: Andi offset.

Masnur Muslich. 2007. KTSP. Pembelajaran berbasis kompetensi dan kontekstual. Jakarta: Bumi Aksara.

Muhibbin Syah. 1996. Psikologi pendidikan: suatu pendekatan baru. Bandung: Remaja Rosdakarya.

Onong Uchjana Effendy. 2001. Ilmu Komunikasi Teori dan Praktek. Bandung: PT. Remaja Rosdakarya.

Phillips, Rob. 1997. The Developer's Handbook to Interactive Multimedia (A Practical Guide for Educational Appications). London: Kogan Page.

RomiSatriawahono. 2006. Media pembelajarandalamAspekPerangkatLunak. www.romisatriawahono.

Rudi danCepi. 2008. Media Pembelajaran. Hakikat, Pengembangan, Pemanfaatan, dan Penilaian. Bandung: CV. Wacana Prima. 
S H Lee, \& E. Boling. 1999. Screen Design Guidelines for Motivation in Interactive Multimedia Instruction : A Survey and Framework for Designer. Educational Technology.May-June.

Seels Barbara B and Richey, Rita C. 1994. Instructional Technology: The Definition and Domains of the Field. Washington, DC: Associations for Educational Communication and Technology (AECT).

Simonson, M.R. \& Ann. Thompson. 1994. Educational Computing Foundations. New York: Macmillan College Publishing Company.

Snyder, L.T. 1996. Multimedia \& Learning: where's the connection? Developments in business simulation \& experiential exercises, Volume 23.http://sbaweb.wayne.edu/absel/bkl/vol.23/23bp.pdf.

Sri Anitah. 2008. Media Pembelajaran. Solo: UNS Press.

Suciati \& Prasetya Irawan. 2001. Teori belajar dan motivasi . Pusat antar Universitas untuk peningkatan dan pengembangan aktivitas instruksional. Jakarta: Depdiknas Ditjen Pendidikan Tinggi.

Sugiono. 2008. Metode penelitian pendidikan (pendekatan kuantitatif, kualitatif dan $R \& D$. Bandung : PT. Alfabeta.

Suharsimi Arikunto. 1998. Prosedur Penelitian. Jakarta: Rineka Cipta.

Sukarno. 2009. Pengembangan multimedia pembelajaran untuk meningkatkan kemampuan menulis teks berita siswa SMP. Yogyakarta: Tesis UNY.

Sukmadinata. 2006. Metode penelitian pendidikan. Bandung : Program Pascasarjana Universitas Pendidikan Indonesia PT. Remaja Rosdakarya.

Sumarjana. 2008. Pengembangan multimedia interaktif pengenalan alat music tradisional gamelan jawa gaya Yogyakarta. Yogyakarta: Tesis UNY.

Tim Penulis UPI. 2007. Ilmu dan Aplikasi Pendidikan. Bandung : PT. Imperial Bhakti Utama. Undang-Undang SISDIKNAS.(UU RI No. 20 Th.2003).Redaksi Sinar Grafika. Jakarta: Sinar Grafika.

Web quest. Cognitive learning theory.Tahun 2007 from http://suestudent.syr.edu/ebarrtt/ide621/cognitive/html.

Woolfolk, A.E. 1995. Educational psychology.Sixth Edition.Boston :Allyn and Bacon

Zaden, J.W. and Pace , A.J. 1984. Educational psychology in theory and practice. Second Edition New York : Random House, Inc. 